\title{
Arte en Chile: recorridos visuales
}

\author{
Milan Ivelic Kusanovic \\ Instituto de Estética, Facultad de Filosofía, Pontificia Universidad Católica de Chile. \\ milan@ivelic.cl
}

Gaspar Galaz Capechiacci

Instituto de Estética, Facultad de Filosofía, Pontificia Universidad Católica de Chile. ggalazc@uc.cl

La revista Aisthesis ha sido para nosotros un soporte editorial anticipatorio de algunas investigaciones, que han terminado en formato libro con posterioridad. Por eso, nuestro reconocimiento a este órgano oficial del Instituto de Estética de la P. Universidad Católica de Chile. Especialmente en esta ocasión, en que se presenta el ejemplar número 50; notable esfuerzo de dedicación de los integrantes de los comités editoriales como, igualmente, de los directores y colaboradores nacionales y extranjeros que ha tenido en su larga y productiva trayectoria.

Nuestra participación en este número también es un anticipo de la investigación que estamos realizando en torno a las artes visuales en Chile durante los últimos veinticinco años. Es una reseña que describe los recorridos por los cuales transitan treinta artistas chilenos, que pertenecen a generaciones intermedias y promociones más recientes.

Ellos son: Carlos Altamirano, Magdalena Atria, Natalia Babarovic, Mónica Bengoa, Sybil Brintrup, Rodrigo Cabezas, Arturo Duclos, Nury González, Jorge González Lohse, Josefina Guilisasti, Patrick Hamilton, Voluspa Jarpa, Klaudia Kemper, Pablo Langlois, Sebastián Leyton, Enrique Matthey, Norton Maza, Carlos Mantes de Oca, Mario Navarro, Iván Navarro, Alvaro Oyarzún, Sebastian Preece, Pablo Rivera, Demian Schopf, Cristian Silva-Avaria, Enrique Soro, Bruna Truffa, Alicia Villarreal, Andrés Vio y Camilo Yañez.

El proceso de globalización ha llevado a los artistas chilenos a internacionalizar la mirada y deslocalizar su trabajo de arte. Se ubican en un contexto mucho más abierto a los circuitos por donde se mueve la oferta y la demanda artística planetaria. A la vez, se incorporan a las metodologías y recursos que hoy ofrecen las tecnologías de reproducción digital de la imagen. 
Es frecuente su tránsito por otros países, residencias por tiempos más o menos prolongados y participación en sus calendarios expositivos. La mayoría estudiaron en las escuelas universitarias de arte; han profundiza sus estudios en los programas de magíster y doctorado, tanto en Chile como en el extranjero. Poseen rigor metodológico en la investigación y en la experimentación de nuevos recursos materiales e instrumentales.

La transgresión de las fronteras del lenguaje artístico tiene ya una larga data, viene desde los comienzos del siglo xx, con las vanguardias históricas que aparecieron en Europa. Lo que actualmente se advierte es la enorme expansión de dispositivos de la industria reproductora de imágenes, algo impensado algunas décadas atrás. Las maniobras de desplazamiento de los límites han roto con la pureza de los antiguos géneros, confinados a ciertos ámbitos del mundo académico como opciones válidas, pero sin el monopolio que antes tenían.

Se ha debilitado el interés por las manualidades y ha aumentado el uso de las técnicas digitales (3D, por ejemplo) y las prácticas robóticas. Esto no significa que los antiguos ejercicios manuales se hayan extinguido; ellos también han renovado procesos y materialidades.

Cabe recordar que en los años sesenta y sobre todo en los setenta del siglo pasado, se produjo una importante expansión de los límites del arte en el ámbito nacional, como consecuencia del empleo de la fotografía, la fotocopia y el video; el objeto y la instalación; el empleo del cuerpo y la performance; la intervención urbana y el sitio específico. Hay que agregar, en estos últimos decenios, la telefonía móvil y la computación, contribuyendo todos al crecimiento exponencial de la imagen.

Se tomó distancia respecto al estatuto tradicional de representación visual y se buscó una aproximación al espectador, sobre todo a los más jóvenes, quienes están mucho más habituados a la imagen en movimiento que a la imagen fija. Esta expansión no es solo producto de los recursos mediales, sino que, igualmente, de los contenidos temáticos, debido a la observación meditada del entorno, en sus características antropológicas, sociológicas, etnográficas, económicas y culturales.

Esta movilidad lleva al artista a un nomadismo por su constante desplazamiento. Su campo operativo es ilimitado y los recursos técnicos y materiales son cambiantes, a veces mutables. De ahí la hibridación y la mezcla, el travestismo e, incluso, el pastiche.

La mayoría ha asumido una planificación rigurosa; rehúye lo espontáneo y lo no premeditado para aproximarse a una línea de trabajo analítica: el proyecto parece imponerse a la tradicional manualidad del taller. Algunos, incluso, amplían su campo laboral al desempeñarse como curadores, editores o museógrafos. Otros son francotiradores, al margen de cualquiera agrupación convergente por coincidencia de principios o criterios, lo que se traduce en un individualismo acentuado, con la consiguiente dispersión de propuestas dentro del escenario artístico nacional.

¿Cuáles son sus principales recorridos visuales? Uno de ellos, quizás el más investigado, es la ciudad en toda la extensión de su trama urbana. Se orienta a los 
espacios regulados que, en la rutina diaria de sus habitantes, han dejado de ser lugares de vivencias que despierten curiosidad, mucho menos asombro, ni siquiera estímulos sensoriales. Justamente aquí aparece la acción de los artistas destinada a alterar, modificar o trastrocar esa indiferencia, que lleva a los ciudadanos a "no ver" su espacio urbano. Particular importancia conceden al problema de la segregación urbana con toda la carga de marginalidad, pobreza y desamparo en que viven extensos grupos humanos en Chile. Como estas intervenciones son, en general, transitorias y fugaces, solo quedan como testimonios, registros fotográficos o grabaciones en video.

Esta opción de ocupar la ciudad supone renunciar al objeto estético, dejar de lado los lugares específicos y tradicionales de exhibición: museos y galerías; e implica la pérdida del carácter coleccionable que supone su adquisición, exposición y conservación. Su desmaterialización significa su desaparición como objeto tangible $y$, eventualmente, como bien patrimonial. Hay aquí un giro operativo y conceptual al ampliarse el reducto restringido en que se producía y circulaba el arte.

Se trata de una deliberada decisión del artista de no entrar en el circuito oficial de exposición y evitar su inserción en el mercado del arte. La fragilidad de la estructura que construye lo deja al margen de dicho circuito; su propuesta carece de los atributos de permanencia en el tiempo. Al renunciar al mercado, no le queda otra alternativa de financiamiento que buscar ayuda mediante becas, auspicios privados o concursos públicos, como el Fondo de las Artes (FONDART). Este último es el más solicitado y el que más ha colaborado para satisfacer las necesidades presupuestarias que le solicitan.

Otro recorrido de interés corresponde a acontecimientos históricos que han gravitado intensamente en el país. En particular, aquel que se vivió durante la dictadura militar (1973-1990). Para algunos artistas, fue una temática preferente porque vivieron, aunque muy jóvenes, el drama político, que luego hicieron explícito en las imágenes que elaboraron. Otros, que eran menores de edad en el momento del golpe, o no habían nacido aún, recibieron por vía indirecta (familia, prensa, colegio, universidad, entorno social) el conocimiento de ese suceso. Estos artistas incorporaron en sus proyectos testimonios, vestigios y fragmentos de memoria con distintas intensidades.

Un tercer foco de atención es la reflexión sobre el arte en sí mismo, su estructura operacional y sus componentes materiales. En muchos casos, la obra es el proceso, es decir, no se cierra, sino que continúa su desarrollo hasta transformar la base inicial de la cual partió. Hay que recordar que con la modernidad, a comienzos del siglo xx, los artistas no dejaron de interrogar los fundamentos de su propio quehacer. En estos últimos decenios, la postmodernidad ha tensionado más aun aquella interrogante. Considerar, a modo de ejemplo, las ambigüedades, desplazamientos y rupturas que han afectado el saber y desconectado el concepto de totalidad, vinculado a los cánones y convenciones de autoridad.

Otro potente núcleo de estudio es la vida cotidiana que rompe el binarismo entre lo público y lo privado; entre "acciones épicas" y actos domésticos; entre las labores del hogar, colegio, trabajo y vida ciudadana. En fin, entre alta y baja cultura. Los artistas 
realizan un sistemático trabajo de campo destinado a conocer y reflexionar sobre las experiencias diarias de la gente; su situación socio-económica y cultural; sus temores y anhelos; la construcción de sus símbolos, ya sea como ficción de un imaginario que se desea, o como cruda realidad de una vida carente de horizontes.

Estos recorridos visuales que se han reseñado no son necesariamente caminos en un solo sentido, ni mucho menos exclusivos. Siempre existen procesos migratorios que llevan al artista a desviarse de su trazado, a cruzarse con los de otros, a interactuar con el otro. Se trata de ampliar la cartografía artística para llegar, quizás, a delimitarla por completo. 